\title{
Biofuels in the Quest for Sustainable Energy Development
}

\author{
Ibrahim Khalil Adam \\ Department of Biochemistry \& Molecular Biology \\ Nasarawa State University, Keffi Nigeria \\ $\&$ \\ Centre for Plant Sciences, Faculty of Biological Sciences \\ University of Leeds, LS2 9JT, Leeds, UK \\ Ahmad Galadima (Corresponding Author) \\ Department of Pure and Applied Chemistry \\ Usmanu Danfodio University, P.M.B. 2346, Sokoto Nigeria \\ $\&$ \\ Surface Chemistry and Catalysis Research Group \\ Unversity of Aberdeen, AB24 3UE, Aberdeen, UK
}

Tel: 44-75-5321-3114Ｅ-mail: ahmadgldm@yahoo.com

Auwalu Inuwa Muhammad

Abubakar Tafawa Balewa University, Bauchi, Nigeria

$\&$

Drilling and Well Engineering Department

The Robert Gordon University, Aberdeen, UK

Received: February 9, 2011

Accepted: March 9, 2011

doi:10.5539/jsd.v4n3p10

\begin{abstract}
The numerous energy challenges facing the world coupled with the lack of sustainability of the non-renewable "fossil fuels world" has led the search to sustainable alternatives. Biofuel has emerged as an alternative with great promise with quite some problems to contend with; this include the development of feasible technologies such as the search for highly efficient saccharification enzymes; and the high cost of production which make the fuel price exorbitant. Thus there is need for cheap processing technologies in order to make the biofuels affordable. We reviewed lots of progress made on biofuel development and some cutting-edge technologies being developed for their production.
\end{abstract}

Keywords: Biofuels, Development, Alternatives, Energy, Challenges

\section{Introduction}

Energy is highly indispensable to our day to day activities and is required in all sectors of the economy including industry, agriculture and transportation among others for sustainable economic growth and development. The requirement is on a high increase due to rapid industrialization and huge numbers of vehicles (Agarwal, 2007; Worldwatch Institute., 2007; Kajikawa and Takeda, 2008). The major sources of energy today are the non-renewable sources which include crude oil, nuclear power, coal, propane, natural gas (Johansson and Burnham, 1993; Stevens and Verh, 2004). The transport sector consumes larger amount of this non-renewable fossil fuels, primarily the petroleum-based fuels others are coal and natural gas. Crude oil forms $35 \%$ of the global energy consumption (Festel, 2008; Kohli et al., 2009).

The limited reserves of fossil fuel and its depletion are issues of concern due to geometric increase in energy demand as a result of developing economies and transportation demands. The increase energy demand and high rate of consumption of fossil energy limits its availability; concerns have been shown that the world oil reserves 
will be depleted earlier than the predicted as a result of increase in world population to 8 billion by 2025 (Agarwal, 2007; Worldwide Institute, 2007; Kohli et al., 2009). The emission of green house gases $\left(\mathrm{CO}_{2}\right.$ and $\mathrm{CH}_{4}$ ) by gasoline and diesel automobiles is a major source of environmental contamination; the combustion of fossil fuels contributes significantly to global warming and acid rain. The global temperature is expected to rise by $6.4^{\circ} \mathrm{C}$ by the end of the $21^{\text {st }}$ century; this increase is attributed to high increase in green house gases with consequent effects on the fauna and flora (Agarwal, 2007; Kohli et al., 2009). The price of crude oil, natural gas and coal is affected by lots of factors making it unstable and unpredictable. The significant use of petroleum based fuels in transportation and other sectors leaves a footprint on prices of commodities as the prices increase. Between 2002 and 2008, the price of crude oil rose from US\$30 to above US $\$ 130$ per barrel which is greater than fourfold increase. The high price of crude oil affects economic growth and efficient use of energy. This is coupled by tight regulations on emissions of wastes from fossil fuels and other sources of non-renewable energy in Europe and USA (Agarwal, 2007; Kajikawa and Takeda, 2008; Kohli et al., 2009).

Other issues affecting the fossil energy include monopoly by oil producing countries, energy security, rising political and economic conflicts. The petroleum exporting countries have a significant influence on the price of this commodity by determining the amount of crude oil supplied to the market hence regulating its price (Agarwal, 2007; Demirbas, 2007). Dependence and reliance on crude oil may be responsible for conflicts in various regions where it is being produced, as any conflicts in those areas affects the supply and hence the market price. Thus, affecting the socioeconomic welfare of the populace (Hill et al., 2006; Agarwal, 2007; Demirbas, 2007). Consequently, the lack of sustainability of the non-renewable energy is obvious thus; the need for sustainability in the energy sector cannot be overemphasized due to the damaging consequences of non-renewable fuels. A sustainable development can be described as a development that satisfies the need of today without compromising that of tomorrow. Thus biofuels are considered as sustainable energy alternatives with great potentials (James, 2008; Taylor, 2008). The paper therefore reports the progress made in this respect. Important global issues regarding biofuels production and usage are reviewed.

\section{Renewable Energy as an alternative}

The lack of sustainability of non-renewable energy has necessitated the search for renewable energy sources which include; wind, geothermal, hydro (water), solar energy, bioenergy (biomass), photovoltaic (Johansson and Burnham, 1993; Stevens and Verh, 2004). Bioenergy (biofuel) is considered as a potential source of energy due to its numerous and overwhelming environmental, socioeconomic benefits including rural development, land and soil reclamation (Farrell et al., 2006; Hill et al., 2006; Schubert, 2006; Vertès et al., 2006; Agarwal, 2007; Demirbas, 2007; Righelato and Spracklen, 2007). Developing countries such as China, India, and Brazil are considered as the major sources and markets for renewable energy due to the need to meet their energy demand owing to rapid industrialization and high population increase (Kohli et al., 2009). Huge amount of energy is consumed as electricity, power, heat and fuels in residential, commercial, industrial and transport sectors. Transportation consumes as much as $22 \%$ of the energy supplied globally and is a major contributor to environmental pollution by $27 \%$ of the global $\mathrm{CO}_{2}$ emissions. It is predicted that consumption rate by transportation will increase due to huge number of vehicles currently amounting to over half a billion (Agarwal, 2007: Kohli et al., 2009).

\subsection{Biofuels}

Biofuels refer to liquids or gaseous fuels produced from biomass for the transport sector. Bioenergy is fundamental to civilization and represents a significant proportion of global energy consumption and is demonstrating a great promise over time (Kumar and Sharma, 2008; Taylor, 2008). The use of biofuel is not new; Dr. Rudolf Diesel's engine (1900) ran on 100\% peanut oil which was abandoned in 1920 due to popularity and availability of petrol-diesel but, he predicted a return to biofuel, in particular use of vegetable oils as biodiesel (Agarwal, 2007; Kohli et al., 2009). First generation biofuels are bioethanol produced from fermentation of sugar and starch, and biodiesel from edible oil seeds, Second generation biofuels are bioethanol and biobutanol from lignocellulosic biomass, biodiesel from non-edible plants. Third generation biofuels also referred to as advanced biofuels are produced from microalgae and cyanobacteria; biohydrogen and bioelectricity generation using photosynthetic methods may be regarded as fourth generation biofuels (Festel, 2008; Gressel, 2008; Gouveia and Oliveira, 2009).

The popularity and acceptance of biofuels is increasing across the globe, currently countries in Europe, USA, Brazil, India, China and some parts of Africa are focussing on biofuel production and use as blends or otherwise (Demirbas, 2007; Kohli et al., 2009). Bioethanol, biodiesel, biogas, bioalcohols including biopropanol, 
biobutanol and biomethanol are alternatives to fossil fuels produced from different feedstocks, lignocellulose and oil crops. Bioelectricity is produced using hydrogen fuel cell (Demirbas, 2007; Kohli et al., 2009).

\subsubsection{Biofuels; Sources and Production}

The expensive cost of producing biogas, biopropanol and biobutanol limits their use; bioethanol is produced and used widely in Brazil while some countries favour the use of biodiesel. Bioethanol is produced by fermentation from corn (maize), cassava, sugar cane, sugar beet and various lignocelluloses biomass. Hydrolytic conversion of carbohydrates (hemicelluloses and cellulose) in plants is a route to bioethanol production; this is a yeast catalyzed anaerobic conversion or digestion of sugars to alcohol. Anaerobic hydrolysis of biological wastes results in the production of biogas which is a mixture of methane and carbon dioxide (Demirbas, 2007). Bioethanol is a promising biofuel that can be derived from any material containing simple or complex sugars. It can be produced from sugar cane and starchy foods such as corn, wheat, potatoes. Lignocellulose has been described as the most promising raw material, cellulose is the most common biopolymer present in wood, organic industrial wastes and is a polysaccharide that can be converted into sugars and fermented. Thus, bioethanol from lignocellulosic materials has the potential to be a valuable substitute for, or complement to, gasoline (Piccolo and Bezzo, 2009). The polysaccharides cellulose and hemicellulose in lignocellulose, are not readily available. The conversion to ethanol requires chemical pre-treatment, normally carried out in ethanol production plant, to free the carbohydrates. Lignin, which is a common constituent of plant cell walls is a complex of phenylpropanoid groups (Anderson and Akin, 2008; Okuda et al., 2008). Lots of processes for the production of bioethanol from lignocellulosic biomass are being developed; this includes enzymatic hydrolysis and fermentation process and gassification (Piccolo and Bezzo, 2008). Figure 1 shows industrial routes to bioethanol production. Thermochemical methods, acid hydrolysis and enzymatic hydrolysis have been described as means of making ethanol from lignocelluloses (Watz, 2008). However cheaper carbohydrate sources of bioethanol are been envisaged to reduce the cost of production and consequently energy cost (Mohanty et al., 2009). Table 1 shows global outlook of fuel ethanol production.

Ethanol has powered automobiles for more than a century. Ford designed his model $\mathrm{T}$ for ethanol as a fuel. Gradually petroleum took over and became the dominating transport fuel. In the seventies Brazil adopted an ethanol strategy and today motor fuel grade ethanol (MFGE) is an extremely fast growing market worldwide. The main outlet for bio-ethanol is as automobile fuel. Total world production reached 50 billion litres in 2007 and still increasing. Fossil oil is coming to an end within a foreseeable future, and for transport a liquid replacement is required. There is possible competition from other products like methanol, but they have to be derived from the same feedstocks - and ethanol is by far the most engineered product today.Another emerging application still in the cradle but with a growing potential is alcohol for Direct-ethanol fuel cells or DEFCs converting ethanol direct to electricity. The technique resembles that of Direct-methanol fuel cells or DMFCs with small portable units already on the market. An alcohol stove burns pure and does not require a chimney. A popular consumer item - just hang it on a nail.

Bioethanol is renewable, because it is made from glucose created in green plants by the sun, the so called photosynthesis:

(A) $6 \mathrm{CO}_{2}+6 \mathrm{H}_{2} \mathrm{O}+$ sunshine $\rightarrow \mathrm{C}_{6} \mathrm{H}_{12} \mathrm{O}_{6}+6 \mathrm{O}_{2}$

Sun energy transforms carbon dioxide $\left(\mathrm{CO}_{2}\right)$ into glucose $\left(\mathrm{C}_{6} \mathrm{H}_{12} \mathrm{O}_{6}\right)$. This glucose is transformed once again to ethanol $\left(\mathrm{C}_{2} \mathrm{H}_{6} \mathrm{O}\right)$ by classic yeast fermentation:

(B) $\mathrm{C}_{6} \mathrm{H}_{12} \mathrm{O}_{6} \rightarrow 2 \mathrm{C}_{2} \mathrm{H}_{6} \mathrm{O}+2 \mathrm{CO}_{2}+$ heat

Heat is released calling for cooling of the fermentation vessels and heat is released again when the ethanol is burned in the combustion engine:

(C) $\mathrm{C}_{2} \mathrm{H}_{6} \mathrm{O}+3 \mathrm{O}_{2} \rightarrow 2 \mathrm{CO}_{2}+3 \mathrm{H}_{2} \mathrm{O}+$ heat

The three equations clearly demonstrate why bioethanol is said to be $\mathrm{CO}_{2}$-neutral. Only the $\mathrm{CO}_{2}$ - absorbed during the photosynthesis - and no more - is released by the engine. The equations also explain why bioethanol is considered a form of solar energy. All the $\mathrm{CO}_{2}$ and water $\left(\mathrm{H}_{2} \mathrm{O}\right)$ absorbed by the green plants are released again. All the three processes - photosynthesis, fermentation and burning - do (all together), is in fact, to turn sun light into heat. Bioethanol is friendly to the environment. As a liquid it is a convenient form of solar energy and may replace gasoline or part of it in modern transportation. Conventional motors tolerate mixtures of as much as $10 \%$ ethanol in the petrol (E10). Newer motors are built to tolerate up to $85 \%$ ethanol (E85) and we will see more motors able to run on pure ethanol (E100) in the future.

Biodiesel are fatty acid (m)ethyl esters (FAMEs) produced from fresh or used vegetable oil, or used animal fats. Biodiesel can be produced from both edible and non-edible oil crops such as soy, rapeseed oil, cotton, palm oil, 
sun flower oil, sunflower, linseed, peanuts, soapnut seed (Sapindus mukorossi), Jatropha curcas and Pongamia pinnata (Kohli et al., 2009; Agarwal, 2007; Demirbas, 2007; Achten et al., 2008; Chhetri et al., 2008; Antczak et al., 2009). Biodiesel is produced through transesterification reaction (stages 1 to 3); that is a reaction of fat or oil with an alcohol to form esters and glycerol. Filtration is performed to remove water and contaminants which is then followed by pre-treatment to remove or esterified to transform free fatty acids into biodiesel (Agarwal, 2007; Demirbas, 2007; Kohli et al., 2009).

Stage 1:

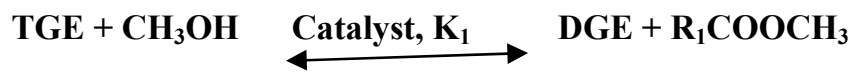

Stage 2:

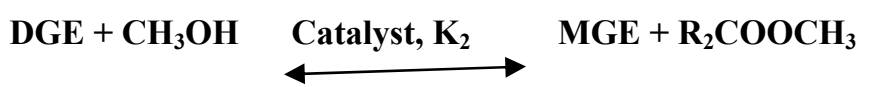

Stage 3:

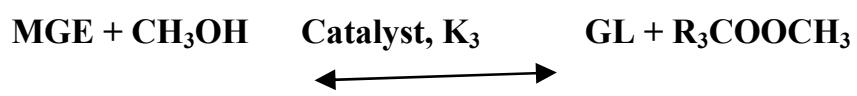

Overall then,

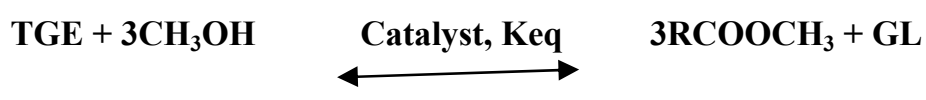

Where DGE, MGE and TGE are diglyceride, monoglyceride and triglyceride esters respectively. GL is the glycerol produced and $\mathrm{K}_{1}, \mathrm{~K}_{2}$, and $\mathrm{K}_{3}$ are the equilibrium constants for stages 1 to 3 respectively. Keq is the overall equilibrium constant. The various Rs represent the long chain alkyl groups attached to the esters.

Pre-treatment is essential for recycled animal fat with more than $4 \% \mathrm{w} / \mathrm{v}$; here the oils are mixed with methanol and catalyst ( $\mathrm{NaOH}, \mathrm{KOH}$, mineral acids like $\mathrm{H}_{2} \mathrm{SO}_{4}$, and solid acids and bases) to transesterify the triglycerides into FAMEs (biodiesel) and glycerol (Figure 2). In the final stage the glycerol is separated and the fatty acid methyl esters can then be used as biodiesel (Agarwal, 2007; Demirbas, 2007; Achten et al., 2008). Another important step in biodiesel production is oil extraction; oil is extracted using highly efficient expellers that extract high amount of oil from the seeds hence increasing the value of biodiesel. Two methods are mostly used which are mechanical and chemical extractions (Achten et al., 2008; Kumar and Sharma, 2008). In the chemical method; only ground plant samples are used as feeds shells can be used as by-products of combustion or gasification of feed stocks; n-hexane extraction method is widely used gives maximum oil yield but is time consuming. Generation of waste water, high energy consumption, and high emissions of volatile organic compounds and use of hazardous and inflammable chemicals makes it unfavourable (Achten et al., 2008). A global statistic of biodiesel production is given in Table 2. It can bee seen that, the production is increasing over the years. This could be attributed to the most recent concerns on the foreseeable consequences of global warming and the depletion of fossil fuel reserves.

Developed countries like United Kingdom have implemented a regulatory policy requiring $5.75 \%$ blend in diesel fuel. In developing countries like Nigeria the recent biofuels policy seeks to ensure $20 \%$ blend ratio by 2010 (Galadima and Garba, 2009).

On the other hand, the process of biogas production takes place in anaerobic conditions and in different temperature diapasons (in biogas digester, common example shown in figure 3). There are psychrophilic (temperature diapason $\left.10-25^{\circ} \mathrm{C}\right)$, mesophilic $\left(25-40^{\circ} \mathrm{C}\right)$ and thermophilic $\left(50-55^{\circ} \mathrm{C}\right)$ regimes of bioconversion. Biogas production in a thermophilic regime is much higher than for the mesophilic and psychrophilic regimes. Modern thermophilic bioreactors can produce $2-6 \mathrm{~m}^{3}$ per $\mathrm{m}^{3}$ of installation, which amounts to $5-15 \mathrm{~kg}$ of waste on a dry mass base (or 50-150 kg of wet mass). For mesophilic biogas installations, these values are $0.2-0.4 \mathrm{~m}^{3}$ per $\mathrm{m}^{3}$ of installation and $0.5-1 \mathrm{~kg}$ on a dry mass base (or 5-10 kg of wet mass). Biogas reactors, working in a thermophilic regime, can be introduced in agricultural farms where the number of livestock exceeds five. Biogas produced on such farm scan be used not only for cooking and heating water, but for dairy production as well.

\subsubsection{Non-edible Sources of Biofuels}

As has been described above there is urgent need of exploiting non-edible material for the production of biofuels as against the use of food to tackle the contextual food versus fuel debate. The production of bioalcohols such as 
bioethanol and its derivatives from lignocellulosic biomass is gaining wide acceptance (Piccolo and Bezzo, 2009). In the same vein a number of non-edible oilseeds are considered for the production of biodiesel as against the edible oil food; these include Sapindus mukorossi, Pongamia pinnata and Jatropha curcas. Both Sapindus mukorossi (soapnut) and Jatropha curcas are considered to be potential for biodiesel production (Chhetri et al., 2008; Kohli et al, 2009).

\section{The Role of Biotechnology in Biofuels Production}

The full realisation of the potentials of biofuel plants requires the improvement of crop. There are lots of developments in enzyme production and cell wall biology which will greatly help in the realization of sustainable biofuel production. In lignocellulosic biomass there is need to modify lignin such that the cellulose is made more accessible for hydrolysis. This was demonstrated in an effort to increase ethanol production from lignocellulose biomass, genes involve in lignin synthesis were knocked down using antisense technology and bioethanol yield from the plant doubled or tripled (Chen and Dixon, 2007; Gomez et al., 2008).

Biotechnology is considered as an efficient means of biofuel production and enhancing the yield of biofuels by removing the current bottlenecks such as poor yield, toxins and improving agronomic traits of crops (Gressel, 2008; Lynd et al., 2008; Sujatha et al., 2008). For biodiesel crops like Jatropha curcas, toxicity, and high amount of free fatty acids limit their full potential; these and other problems can be solved using molecular approaches. Consequently improving the traits of biofuels crops will remove some of the bottlenecks and increase their economic value. For instance, the number of seed yield per plant can be improved using strategies such as marker-assisted selection of qualitative planting seeds (Kumar and Sharma, 2008). Though biotechnology can be promising in improving bioenergy production but caution should be given on the ethics, biosafety and biocontainment as regards the of use the transgenic approaches (Stewart, 2007).

The up regulation of genes involved in lipid biosynthesis, storage and oleosome formation while on the other hand silencing those genes involved in toxin synthesis in biofuel plants such as Jatropha curcas can be achieved using transgenic approaches thus improving the plant but this requires knowledge of the gene expression (Popluechai et al., 2009). Curcin promoter has been isolated from Jatropha curcas indicating that there is potential of isolation and characterization of the different genes in toxin production and lipid acid biosynthesis. Li and colleagues recently reported an Agrobacterium-based transformation of Jatropha curcas cotyledon demonstrating the potentials of developing transgenic varieties with desired traits ( $\mathrm{Li}$ et al., 2008). This and others are giving lots of promise on the success of improving the biofuel crops.

\subsection{Potential of Biofuels}

Biofuel is considered to have great potentials the full realisation of which will be a matter of time; these potentials are driving lots of interests from countries both developed and developing countries. Biodiesel production and consumption in the EU countries is on the increase, over 4.8 million tones of biodiesel was produced by EU27 in 2006. USA increased its biodiesel production from soy oil to over 250 million gallons in 2006 from 20 million gallons in 2003 (Kohli et al., 2009). Twenty percent substitution of conventional fossil fuels with alternative fuels in the transport sector by 2020 is the target of the European Commission. The US is set to replace more than $75 \%$ of imported oil with alternative fuels by the year 2025 (Kajikawa and Takeda, 2008). The market for biofuels in general and biodiesel in particular is large due to the high and increasing demand. Germany and France use rape seed oil for biodiesel production. Scientists are considering biodiesel production from green algae and bacteria using genetic engineering techniques (Kohli et al., 2009). The numerous benefits of biofuels include sustainability, mitigation of green house gases emissions, regional developments, employments, energy security, conflict resolutions, agriculture and socioeconomic benefits (Kohli et al., 2009; Hill et al., 2006; Schubert, 2006; Agarwal, 2007; Demirbas, 2007; Righelato and Spracklen, 2007). The use of ethanol-blended fuels such as E85 (85\% ethanol and 15\% gasoline) can reduce the net emissions of greenhouse gases by as much as 37.1\%, which is a significant amount. Between the year 1975 and 1987, ethanol production saved Brazil $\$ 10.4$ billions. A recent research concluded that by 2050, biofuels theoretically, could supply $65 \%$ of the world's current energy consumption, with sub-Saharan Africa, the Caribbean, and Latin America accounting for roughly half of this global potential. In tropical countries, high crop yields and lower costs for land and labour provide an economic advantage that is hard for countries in temperate regions to match (Edward et al., 2004). In addition to potential role in climate change mitigation biogas greatly influences economic growth and energy supply to local inhabitants in many countries. For example, biogas is at the centre of a burgeoning eco-economy in China. Up to the end of 2005, China has 17 million digesters with annual production of 6.5 billion $\mathrm{m}^{3}$ biogas, mostly in rural areas, with 50 million people enjoying the benefits of biogas 
technology. The annual production of biogas is projected to reach 25 billion $\mathrm{m}^{3}$ by 2020 . Biogas could provide energy to one quarter of households in rural areas (Kangim and Ho, 2006).

\subsection{Problems associated with biofuels}

Lots of issues have been raised by researchers that may limit the realisation of biofuel potentials of biomass. The most striking problem affecting the production and utilization of biofuels is the fuel versus food debate that has attracted so many arguments. The high cost of production of biofuels at the moment makes their prices high. In term of biodiesel some of the limiting factors are low performance in cold temperatures leading to corrosion of rubber components. Though this can be overcome by the use of antifreeze and improvement in the tubing materials but more work is required to resolve this (Agarwal, 2007; Demirbas, 2007; Kohli et al., 2009). The use of edible food such as soy, rape seed, and palm for biodiesel production against feeding is not sustainable as it affects the amounts of food available and reduces availability of land for agriculture. The predicted increases in world population coupled with availability of water bring about the need for alternatives to edible oil. Thus various non-edible oil crops, woody plants and waste conversion to biodiesel are considered as potential alternatives (Chhetri et al., 2008; Kohli et al., 2009). People have expressed concerns over the net effects of biofuels on agricultural land, water, food supply and rise in the price of food, but this is attributed to other factors but not biofuels as there are lots of marginal land resources for farming (Gressel, 2008).

\section{Conclusion}

Biomass or bioenergy has been described as a potentially reliable and renewable energy resource, and is promising in this regard. Thus, the interest in bioenergy and biofuels is intensifying due to their renewability and sustainability. Currently biofuels provide a significant amount of global energy consumption for domestic purposes in both developed and developing countries. The major biofuels produced are ethanol, biodiesel and biogas. Global ethanol production in 2008 was estimated to be 17, 335.2 million gallons, mostly used in the automobiles industry. The figure is projected to exponentially increase for future years. This could be achieved through proper governments policies and upgrading the current synthetic technologies. Biodiesel on the other hand, experienced a global increased in production from 77.2 million gallons in 2005 to 308.2 million gallons in 2009 , with expectations for increased production in the recent years. While the ethanol is mixed with gasoline, biodiesel is used as B20 (20\%) blend with the conventional diesel. Research indicates that several engines that could run on $100 \%$ biodiesel or bioethanol are under constructions. Biogas production and utilisation has also been identified to be on the increased. In countries like china production will increase from less than 10 billion $\mathrm{m}^{3}$ in 2005 to over 25 billion $\mathrm{m}^{3}$ in 2020 . Over 30 million rural inhabitants are considered to be the key beneficiaries.

The positive and negative arguments on biofuels are obvious due to lots of issues. The proponents of biofuels consider the increased global oil demand, energy security problem due to depletion of petroleum reserves, and concern about environmental pollution. In order to produce biofuels on commercial scale, their impact on other energy sources and sectors such as food and textile production must be resolved by new and improved production technologies. In the main, to ensure sustainability in the production and consumption of energy there is need to intensify efforts in search for renewable energy sources that have less impact on the availability and use of other resources with their productions being cost effective. The current technologies available for biofuels production should be improved by funding, and ensuring reliable research globally. Collective approach involving enhanced government policies, industrial and farmers' participation is necessary. Emphasis should always be given to non-edible crops and pre-exploited agricultural land to avoid food shortage and environmental degradation.

\section{References}

Achten, W.M.J., Verchot, L., Franken, Y.J., Mathijs, E., Singh, V.P., Aerts, R., and Muys, B. (2008). Jatropha bio-diesel production and use. Biomass and Bioenergy 32: 1063-1084.

Agarwal, A.K. (2007). Biofuels (alcohols and biodiesel) applications as fuels for internal combustion engines. Progress in Energy and Combustion Science. 33: 233-271.

Anderson W. F and Akin D. E. (2008). Structural and chemical properties of grass lignocelluloses related to conversion for biofuels. J Ind Microbiol Biotechnol. 35: 355-366

Biomass Energy Data Book [BEDB]. (2010). Energy Efficiency and Renewables. U.S. Department of Energy.

Chen, F., and Dixon, R.A. (2007). Lignin modification improves fermentable sugar yields for biofuel production. Nature Biotechnology. 25: 759-761. 
Chhetri, A.B., Tango, M.S., Budge, S.M., Watts, K.C., and Islam, M.R. (2008). Non-edible plant oils as new sources for biodiesel production. International Journal of Molecular Sciences. 9: 169-180.

Demirbas, A. (2007). Progress and recent trends in biofuels. Progress in Energy and Combustion Science. 33: $1-18$.

Edward Smeets et al. (2004). A quickscan of global bio-energy potentials to 2050," Copernicus Institute, Mar. 2004, p. 2 (http://www.chem.uu.nl/nws/www/publica/e2004-109.pdf).

Farrell, A.E., Plevin, R.J., Turner, B.T., Jones, A.D., O'Hare, M., and Kammen, D.M. (2006). Ethanol can contribute to energy and environmental goals. Science. 311: 506-508.

Festel, G.W. (2008). Biofuels - Economic aspects. Chemical Engineering and Technology. 31: 715-720.

Galadima, A. and Garba, Z. N (2009). Catalytic Synthesis of ethyl ester from some common oils. Science World Journal, Vol 4 (No 4): 1-5

Gomez L. D., Steele-King C. G. and McQueen-Mason S. J. (2008). Sustainable liquid biofuels from biomass: the writing's on the walls. New Phytologist .178: 473-485

Gouveia, L., and Oliveira, A.C. (2009). Microalgae as a raw material for biofuels production. Journal of Industrial Microbiology and Biotechnology. 36: 269-274.

Gressel, J. (2008). Transgenics are imperative for biofuel crops. Plant Science. 174: 246-263.

Hill, J., Nelson, E., Tilman, D., Polasky, S., and Tiffany, D. (2006). Environmental, economic, and energetic costs and benefits of biodiesel and ethanol biofuels. Proceedings of the National Academy of Sciences of the United States of America 103: 11206-11210.

James, C. (2008). Global Status of Commercialized Biotech/GM crops. In ISAAA Briefs.

Johansson, T.B., and Burnham, L. (1993). Renewable energy: sources for fuels and electricity. London, Washington, D.C.: Earthscan ; Island Press.

Kajikawa Y., and Takeda Y. (2008). Structure of research on biomass and bio-fuels: A citation-based approach. Technological Forecasting \& Social Change. 75: 1349-1359.

Kangim, L. and Ho, M. (2006). Biogas China. Institute of Science in Society, Science Society Sustainability. ISIS Report 02/10/06. Available on 02 March, 2011 from: http://www.i-sis.org.uk/BiogasChina.php

Kohli, A., Raorane, M., Popluechai, S., Kannan, U., Syers, J.K., and O'donnell, A.G. (2009). Biofuels: Jatropha curcas as a novel, non-edible oilseed plant for biodiesel. In Environmental Impact of Genetically Modified Crops. Ferry, N., and Gatehouse, A.M.R. (eds). Cambridge: MA: CABI.

Kumar, A., and Sharma, S. (2008). An evaluation of multipurpose oil seed crop for industrial uses (Jatropha curcas L.): A review. Industrial Crops and Products 28: 1-10.

Li, M., Li, H., Jiang, H., Pan, X., and Wu, G. (2008). Establishment of an Agrobacteriuim-mediated cotyledon disc transformation method for Jatropha curcas. Plant Cell, Tissue and Organ Culture 92: 173-181.

Lynd, L.R., Laser, M.S., Brandsby, D., Dale, B.E., Davison, B., Hamilton, R. et al. (2008). How biotech can transform biofuels. Nature Biotechnology. 26: 169-172.

Mohanty S. K., Behera S., Swain M. R., Ray R. C. (2009). Bioethanol production from mahula (Madhuca latifolia L.) flowers by solid-state fermentation. Applied Energy 86: 640-644

Openshaw, K. (2000). A review of Jatropha curcas: An oil plant of unfulfilled promise. Biomass and Bioenergy. 19: $1-15$.

Okuda, N., Soneura M., Ninomiya K., Katakura, Y., and Shioya S. (2008). Biological detoxification of waste wood hydrosylate using Ureibacillus thermosphaericus. Journal of Bioscience and Bioengineering. 106: 128-133

Piccolo and Bezzo Fabrizio. (2009). A techno-economic comparison between two technologies for bioethanol production from lignocellulose. Biomass and Bioenergy. 33: $478-49$.

Popluechai, S., Chardot, T., Gatehouse, A.M.R., and Kohli, A. (2008). Characterisation of Jatropha curcas Oil Bodies and Oleosins: A Systems Approach. In Jatropha International Congress. Singapore.

Popluechai, S., Breviario, D., Mulpuri, S., Makkar, H.P.S., Raorane, M., Reddy, A.R. et al. (2009). Narrow genetic and apparent phenetic diversity in Jatropha curcas: initial success with generating low phorbol ester interspeific hybrids. In Nature Precedings: Newcastle University. 
Righelato, R., and Spracklen, D.V. (2007). Carbon mitigation by biofuels or by saving and restoring forests? Science 317: 902.

Schubert, C. (2006). Can biofuels finally take center stage? Nature Biotechnology. 24: 777-784.

Stevens, C.V., and Verh*, R. (2004). Renewable bioresources : scope and modification for non-food applications. Hoboken, N.J.: J. Wiley.

Stewart, C.N. (2007). Biofuels and biocontainment [3]. Nature Biotechnology. 25: 283-284.

Sujatha, M., Reddy, T.P., and Mahasi, M.J. (2008). Role of biotechnological interventions in the improvement of castor (Ricinus communis L.) and Jatropha curcas L. Biotechnology Advances 26: 424-435.

Taylor G. (2008). Biofuels and the biorefinery concept. Energy Policy. 36: 4406-4409.

Vertès, A.A., Inui, M., and Yukawa, H. (2006). Implementing biofuels on a global scale. Nature Biotechnology. 24: 761-764.

Worldwatch Institute. (2007). Biofuels for transport : global potential and implications for sustainable energy and agriculture. Sterling, VA: Earthscan.

Table 1. Global fuel ethanol production by region or country in 2008

\begin{tabular}{lr}
\hline Country & Millions of gallons, all grades \\
\hline U.S. & $9,000.0$ \\
Brazil & $6,472.2$ \\
European Union & 733.6 \\
China & 501.9 \\
Canada & 237.7 \\
Other & 128.4 \\
Thailand & 89.8 \\
Colombia & 79.29 \\
India & 66.0 \\
Australia & 26.4 \\
\hline Total & $\mathbf{1 7 , 3 3 5 . 2}$ \\
\hline
\end{tabular}

Source: BEDB (2010)

Table 2. Global biodiesel production by region and some countries over the years, thousand barrels per day

\begin{tabular}{lrrrrr}
\hline Regin/Country & $\mathbf{2 0 0 5}$ & $\mathbf{2 0 0 6}$ & $\mathbf{2 0 0 7}$ & $\mathbf{2 0 0 8}$ & $\mathbf{2 0 0 9}$ \\
\hline North America & $\mathbf{6 . 1}$ & $\mathbf{1 7 . 1}$ & $\mathbf{3 3 . 7}$ & $\mathbf{4 5 . 9}$ & $\mathbf{3 5 . 2}$ \\
United States & 5.9 & 16.3 & 32.0 & 44.1 & 32.9 \\
Central \& South America & $\mathbf{0 . 5}$ & $\mathbf{2 . 2}$ & $\mathbf{1 5 . 2}$ & $\mathbf{3 8 . 6}$ & $\mathbf{5 7 . 9}$ \\
Brazil & 0.0 & 1.2 & 7.0 & 20.1 & 27.7 \\
Europe & $\mathbf{6 8 . 1}$ & $\mathbf{1 1 3 . 2}$ & $\mathbf{1 3 7 . 5}$ & $\mathbf{1 5 5 . 0}$ & $\mathbf{1 7 2 . 6}$ \\
France & 8.4 & 11.6 & 18.7 & 34.4 & 41.1 \\
Germany & 39.0 & 70.4 & 78.3 & 61.7 & 51.2 \\
Italy & 7.7 & 11.6 & 9.2 & 13.1 & 13.1 \\
Eurasia & $\mathbf{0 . 3}$ & $\mathbf{0 . 3}$ & $\mathbf{0 . 7}$ & $\mathbf{2 . 5}$ & $\mathbf{3 . 8}$ \\
Lithuania & 0.1 & 0.2 & 0.5 & 1.3 & 1.9 \\
Asia \& Oceania & $\mathbf{2 . 2}$ & $\mathbf{9 . 1}$ & $\mathbf{1 5 . 8}$ & $\mathbf{2 8 . 8}$ & $\mathbf{3 8 . 5}$ \\
China & 0.8 & 4.0 & 6.0 & 8.0 & 8.0 \\
Korea, South & 0.2 & 0.9 & 1.7 & 3.2 & 5.0 \\
Malaysia & 0.0 & 1.1 & 2.5 & 4.5 & 5.7 \\
Thailand & 0.4 & 0.4 & 1.2 & 7.7 & 10.5 \\
\hline World & $\mathbf{7 7 . 2}$ & $\mathbf{1 4 2 . 0}$ & $\mathbf{2 0 2 . 9}$ & $\mathbf{2 7 0 . 9}$ & $\mathbf{3 0 8 . 2}$ \\
\hline Source: BED & & & & &
\end{tabular}

Source: BEDB, 2010. 


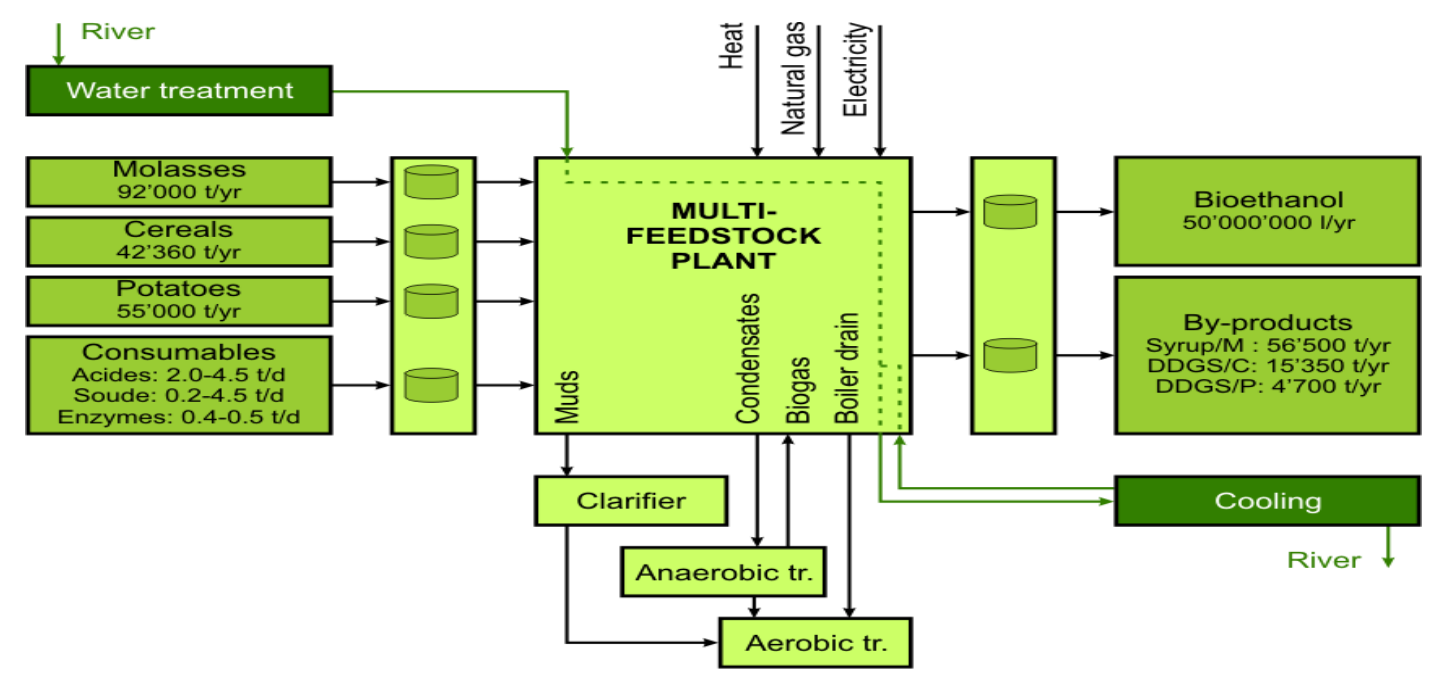

Figure 1. Industrial route to bioethanol production

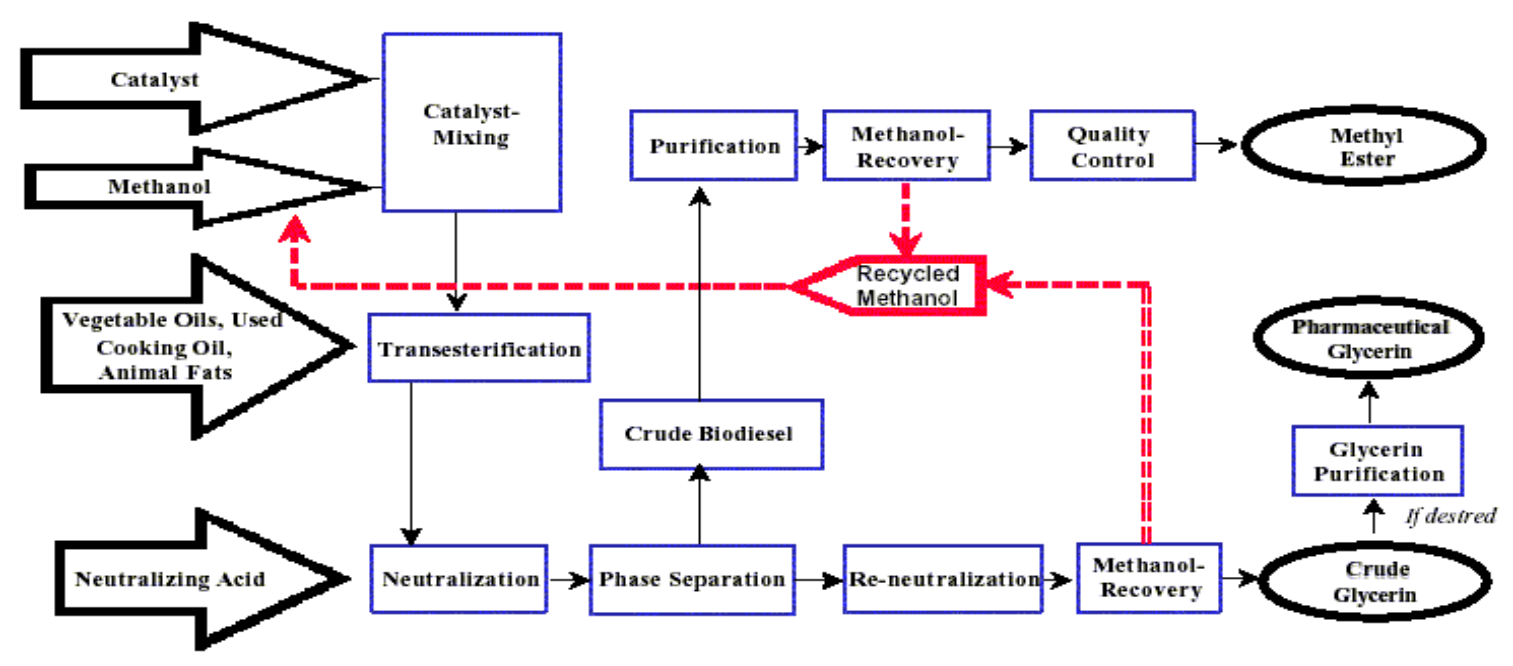

Figure 2. Industrial block diagram for biodiesel production using either homogeneous or heterogeneous transesterification 


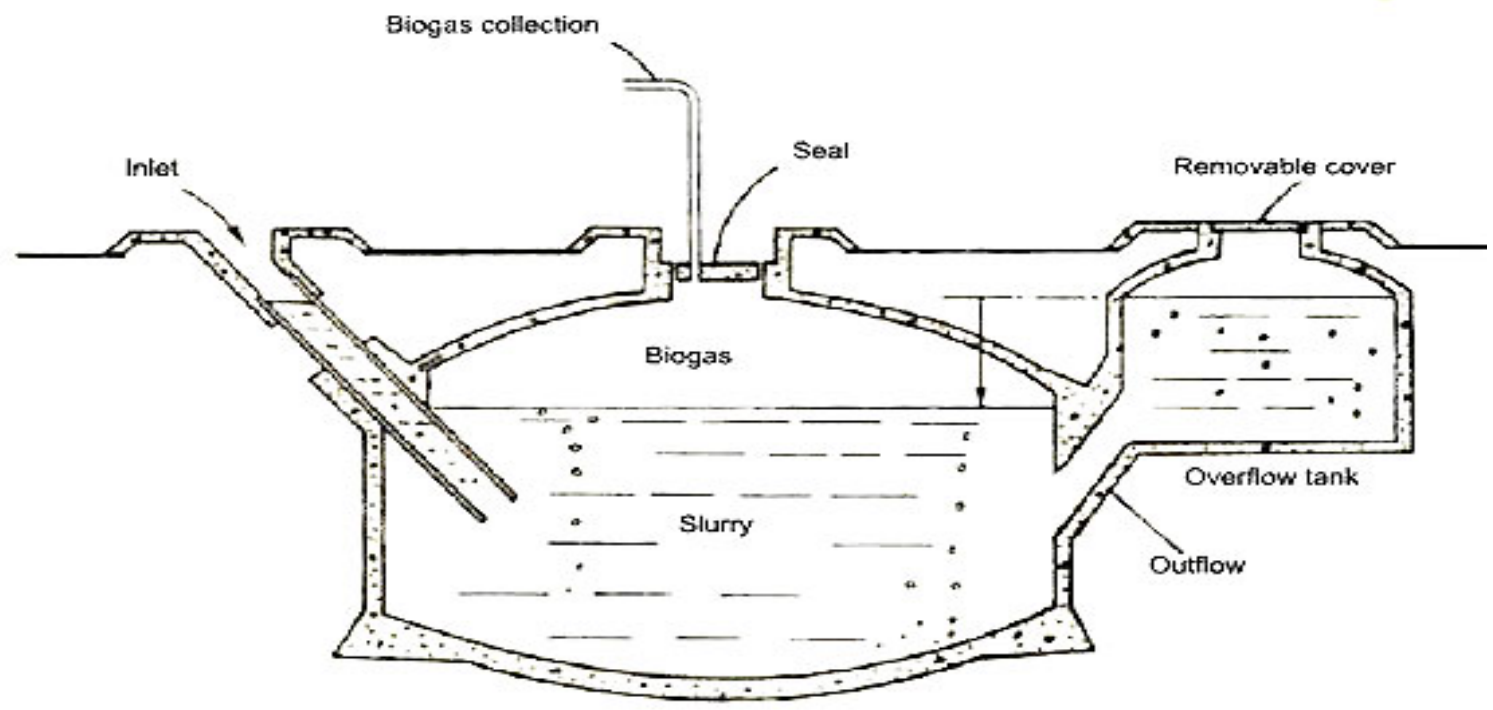

Figure 3. Example of biogas digester widely in used 